\title{
Reflexive practice: To enhance student learning
}

\author{
Joanne Roebuck \\ Law School \\ James Cook University, Australia \\ joanne.roebuck@jcu.edu.au
}

\begin{abstract}
This paper reports on the use of reflexive practice activities designed to enhance learning for first year law students at James Cook University, Australia. The paper considers various aspects of student learning and explores connections between reflexive practice and concepts such as deep learning, understanding, motivation and engagement, and identifies abilities developed by reflexive practice. The paper explores terms such as reflection, reflexivity and reflexive practice, and provides a context, justification and rationale for incorporation of reflexive practice in university curriculum to enhance learning. A description of reflexive practice, informed by Prpic (2005) and adapted for student learning is offered. Learning activities which incorporate reflexive practice are described and potential problems are highlighted.
\end{abstract}

\section{Keywords}

reflection, reflexive practice, deep learning, literacy, first year law student, learning activity, engagement, student retention, constructive alignment, graduate attributes

\section{Context}

James Cook University, Australia, is a medium sized regional university situated in north Queensland, with campuses in Townsville and Cairns. The Law School offers a first year program, across both campuses, to approximately 280 students each year. In 2005, the Law School embarked upon the task of redesigning its first year law program. The invigorated program, named 'The First Year Experience - Law' (FYE-Law), was designed with various principles guiding the reform which addressed enhancing learning (deep learning), alignment of learning across the program and within each subject, student engagement, development of basic and critical literacy, retention, and development of graduate attributes. Universities worldwide are listing desirable graduate attributes similar to those articulated by James Cook University. Desired graduate attributes listed on the JCU website (http://www.jcu.edu.au) include various abilities for literacy, critical thinking, self-reliance, interpersonal understanding, professional and personal ethics, and reflection on learning achievement.

The FYE-Law reform team, when considering design of the new program, were informed by the wider literature on student learning and adhered to a constructivist approach in order to promote deep learning (Biggs, 2003). The reform team set out to design learning activities which would elicit active responses from students, build on what the student already knows, confront and eradicate misconceptions, operate in a positive working atmosphere, emphasise depth of learning rather than breadth of coverage, and support the explicit learning outcomes and objectives of the subject (Biggs, 2003). Learning activities were also designed to be authentic and contextualised (Biggs, 2003) as such approaches enhance broader objectives of knowledge and understanding (Keyes \& Orr, 1996), critical skill development (Havemann, 1995) and ethical awareness (HenrissAnderssen, 2002). 
Accordingly, when turning to the specific task of design of a learning activity, it was important that it created an opportunity for deep learning. The reform team was challenged to motivate students to desire higher level understandings (Gibbs, 1993). To achieve student motivation, the team set out as teachers 'to design enriching and inherently interesting learning experiences [which] inspire and excite [students] to engage with and take responsibility for their learning' (Kift, 2005, p. 1). Biggs (2003) and Gibbs (1993) agree that if the student values the learning and expects to be successful with it, they will be motivated to learn. The FYE-Law reform team could see that learning activities which promoted student ownership and autonomy (supported by feedback from teachers by which students could monitor their progress) would encourage students to value learning, create expectations of success, and motivation would follow.

In designing activities to promote deep learning (Biggs, 2003), a consideration of deep learning as 'real understanding' is relevant. Various authors consider how students 'understand'. While Hinett (2002) views the learning process or understanding, as individual, contextual, relational and developmental, Biggs and Collis (1982) explain understanding in hierarchical and multi-structured terms. Biggs (2003) explains that as understanding deepens or increases in its complexity, it transforms from being quantitative to qualitative. When understanding is qualitative, knowledge moves from being declarative and becomes functional and relational (Biggs, 2003).

Various taxonomies which address learning and educational objectives are well documented in educational literature (Bloom, Engelhart, Furst, Hill, \& Krathwohl, 1956; Krathwohl, Bloom, \& Masia, 1964; Biggs \& Collis, 1984). Bloom et al. (1956) divides learning objectives into six hierarchical stages: knowledge, comprehension, application, analysis, synthesis and evaluation. Le Brun and Johnstone (1994) and Hinett (2002) perceive a need to incorporate learning development strategies which extend the final stage of evaluation. They agree there is a need (at least in law courses) for learning strategies which address development of attitudes, beliefs and values, which are situated in the affective domain (Krathwohl et al., 1964). Le Brun and Johnstone (1994) argue that addressing attitudes, beliefs and values, which are related to subject content, is appropriate, legitimate, relevant, engages students in learning and enhances student learning.

Prpic's (2005) model of reflexive practice, which is discussed later in this paper, appeared to have considerable potential as a framework for student learning activities, as it complemented well the principles which guided the reform of the FYE-Law program, particularly the focus on enhancing learning, student engagement, literacy development and acquisition of desirable graduate attributes. This paper examines Prpic's (2005) model of reflexive practice and explores the concepts of reflection, reflexivity and reflexive practice in order to relate reflexive practice to student learning. Two learning activities which incorporate reflexive practice, designed for first year law students, are described.

\section{Notions of reflexive practice, reflection and reflexivity}

In order to relate reflexive practice to the study of law and indeed learning, it is necessary to consider the concept of reflection, reflexivity and reflexive practice. While these concepts are not new, to many law teachers, and indeed first year law students, they are. Reflexive practice is situated within the sociological concepts of reflexivity as described by Giddens (1990). It is necessary to appreciate that reflexive practice operates with reflection as its fulcrum. Reflection is widely recognised in the literature as a useful learning activity for students and practising professionals across many disciplines. Biggs (1999) notes that 'a reflection in a mirror is an exact replica of what is in front of it. Reflection in professional practice, however, gives back not what it is, but what might be, an improvement on the original' (p. 6). 
Taylor (2002) considers the use of reflection and defines reflection as 'the throwing back of thoughts and memories, in cognitive acts such as thinking, contemplation, meditation and any other form of attentive consideration, in order to make sense of them, and to make contextually appropriate changes if they are required' (p. 3). More specifically, Hinett (2002) describes reflective practice in the context of facilitating learning for law students. She describes reflective practice as an approach which promotes autonomous learning that aims to develop student understandings and critical thinking skills. Hinett (2002) offers a description of student learning which also serves as a rationale for inclusion of learning activities that incorporate reflexive practice. She describes learning as having four main facets. It is individual, as learners draw from their own knowledge and experience. Learning is also contextual, as learners need to understand that the context in which they learn affects how and what they understand. Learning is relational, because to make sense of and achieve understanding of material and experiences, students need to relate new information to existing knowledge and experiences. Learning is also developmental.

Once students make sense of new information and have integrated it into an existing framework of understanding, the student can then make informed choices about what to do next and how to develop their understanding. Prpic's (2005) paper (on reflexive practice for academics to engage in for professional development) became a catalyst for the idea of incorporating reflexive practice into learning activities to enhance student learning. The learning activities described later in this paper (reflective narratives and book club) are structured around student engagement in reflexive practice. It is proposed that reflexive practice, which incorporates deep or quality reflective practice, can be described as a process of inquiry which facilitates appreciation and understanding of contextualised views (outside of the learner's own experience), a deeper learning experience, the development of ideas, and consideration of or actual change. Accordingly, engagement in reflexive practice has the potential to engage students in all aspects of learning as described by Hinett (2002).

Reflexive practice is situated within the sociological concepts of reflexivity, modernity, globalisation and individualism (Giddens, 1990). Giddens (1990) offers a sociological perspective when he states that reflexivity describes 'the connections between knowledge and social life' (p. 697). He explains that as traditional frameworks of society dissolve, new patterns of identity are emerging such that globalisation is forcing people to live in a more open or 'reflexive' way. Giddens (1990) considers that we are all engaged in some level of reflexive practice every day, even if unconsciously, in that we make choices and react to the world we live in:

This means that we are constantly responding and adjusting to the changing environment around us; as individuals, we evolve with and within the larger context in which we live. Even the small choices we make in our daily lives - what we wear, how we spend our leisure time, how we take care of our health and our bodies - are part of an ongoing process of creating and recreating our self-identities. (p. 61).

Giddens (2001) describes the current world as globalised. While he acknowledges that globalisation is multifaceted and debated, he defines it as 'the intensification of worldwide social relations or the growing interdependence between peoples, regions and countries in the world as social and economic relationships come to stretch worldwide' (p. 690). Within this view, he refers to the fact that we are living in 'one world' where our actions have consequences for others, 'world problems' have consequences for individuals. Further, he argues that globalisation has affected our intimate and personal lives as it has entered our homes, workplaces, schools, universities, healthcare systems and communities by the media, internet, popular culture and our personal communications with others. Giddens (2001) considers that individualism abounds in our globalised society. As the influence of guidelines, tradition, and custom (which affect or set social class, gender roles, ethnicity and religious affiliation) have declined in the globalised world, people are now required to construct their own identities. He argues that to be reflexive is to evolve with and within the larger contexts in which we live, which necessitates changing and recreating our self-identities. 
It seems that Giddens' (2001) concept of reflexivity incorporates the notion that change (or at least consideration of it) is integral to growth or learning development. Desirable graduate attributes listed on university websites worldwide refer to abilities for literacy, critical thinking, self-reliance, interpersonal understanding, professional and personal ethics, and reflection on learning achievement. All are abilities which reflexive practice can foster. Against this background, it seemed important that learning activities which engage students in deliberate reflexive practice be designed. If reflection to consider wider contexts was facilitated and encouraged, deep learning and higher level understanding, along with literacy and graduate attribute development could occur. Prpic's (2005) tri-view model for reflexive practice provided a model which could be adapted student learning.

\section{Prpic's model of reflexive practice}

Prpic (2005) describes a model for reflexive practice designed specifically for academic practitioners working in a dynamic professional environment. Her model enables academics to see themselves in the context of their interactions with other individuals, embedded within the multiple contexts in which they work and live. Prpic (2005) has developed a tri-view approach where intra-view, inter-view and trans-view take place, allowing for adaptation to change through deepening understanding of self. She proposes reflexive practice as an ongoing process of examining and refining how we operate in our professional work, and as a tool for developing selfawareness and knowledge. Individual reflection and dialogue with others are essential to this model which emphasises the need to appreciate and understand views outside individual personal experience.

Prpic (2005) claims that embracing her tri-view model of reflexivity will allow us to 'become articulate social beings, able to exercise attributes such as initiative, creativity, independent judgment, oral [and written] communication skills, analysis, critique and synthesis' (p. 405). Accordingly, it is not difficult to appreciate the value of reflexive practice for learning in the university curriculum. Student engagement in reflexive practice has the potential to enhance or deepen the learning experience for the student and foster development of graduate attributes. Le Brun and Macduff (2005) consider that reflexive practice may also equip the student with necessary abilities for effective professional practice.

In Prpic's (2005) tri-view model, intra-view is an initial reflection process where the participant attempts to find deeper understanding of a new concept, an experience, or of self. Understanding and meaning are acquired through active and deliberate individual reflection facilitated by writing in a journal or through meditation or contemplative thinking. Through intra-view, the participants clarify their view or understanding of issues, explore the boundaries of self and find new ways of seeing themselves in the world. Prpic's (2005) model is based upon the underlying principle that the views of the collective matter, and that they serve to aid in the development of knowledge and understanding. As appreciation of wider contexts, views or opinions are not necessarily considered in this initial stage, Prpic (2005) recognises that intra-view has its limitations and proposes two further stages to her model.

In the second stage, called inter-view, active discussion takes place. The aim of discussion is to deepen and broaden personal understandings by sharing views in order to facilitate new understandings. Prpic (2005) refers to Brockbank and McGill (1998) and explains that in interview, the participant may find new reflections as assumptions about knowledge, self and the world are challenged. True engagement in this process requires a commitment to understanding other views. A general discussion may not suffice. Participants need to be willing to share openly and alternate in their role as interviewer and interviewee. The interviewer needs to take the role of naïve inquirer and should ask appropriate, open questions about the interviewee's beliefs, feelings, thoughts and responses. This dialogue gives rise to clarification of ideas and understanding. 
In this stage, difference is highlighted as ethical, cultural or equitable, and various other issues may arise. Prpic (2005) offers a wide range of forums as appropriate for inter-view. She suggests that narrative, mind-mapping, clinical supervision, drama, sharing of personal journals, engaging a critical friend, stories, poetry and collage may all facilitate inter-view.

In trans-view, the final stage of Prpic's (2005) model, the views of all individuals within the community or collective are considered. This stage requires the participant to actively reflect on their initial thoughts in light of new information and discussions brought out in the inter-view stage. Prpic (2005) claims that trans-view may contextualise intra-view and inter-view by highlighting and prioritising what is important to the collective, and that development of new ideas, knowledge or insights, realised in this stage, may give rise to change.

A learning activity built around this model of reflexive practice appeared to have potential to incorporate many dimensions of learning enhancement. It could provide students with an opportunity for acquisition of functional and relational knowledge. Deliberate personal reflection, eliciting outside views, and secondary reflection could move the student beyond acquisition and reproduction of knowledge, and challenge understandings. These processes engage the student in all aspects (particularly the higher levels) of cognitive (application, analysis, synthesis and evaluation) and affective (attitudes, beliefs and value consideration) learning. Additionally, if the student is addressing lower level understanding, that is, declarative or procedural knowledge in their reflection, other learning developments are still taking place as actual content or processes are embedded through engagement in reflection. Exposure, through dialogue, to the multiple contexts which subject material is situated in, may foster curiosity, motivation to learn and result in a deeper learning experience (Biggs \& Moore, 1993; Krause, 2005).

\section{Prpic's (2005) model of reflexive practice adapted as a framework for a learning activity}

Prpic's (2005) model was used to develop the basis of a three-phase learning activity for first year law students. In phase one, the student is required to engage in individual reflection by writing a personal reflection on designated subject material, an observation, an event or a specified activity. Criteria and prompts for reflection, along with examples of reflective writing and explanations of the role of reflection in learning, should be set out in the explanations for the learning activity. For a first year cohort, participation in reflection should be supported and assisted by staff who provide regular constructive feedback to students.

In phase two (the inter-view or dialogue stage) students engage in respectful and non-judgmental dialogue with a tutor (as in the reflective narrative activity described later) or other students (as in the book club activity described later) in order to understand other people's views and to appreciate wider contexts. An appropriate forum in which to conduct the phase two needs to be considered. A one-on-one exchange (reflective narrative) or a face-to-face, small group meeting (book club) may be the most desirable forum, because communication where all the non-verbal signals of communication are apparent, arguably allows for more effective sharing of ideas. Other forums for dialogue are possible and appropriate, especially if restraints such as time and distance affect availability to participate in a face-to-face setting. Accumulating literature on the use of information communication technologies highlights the usefulness of web-boards to facilitate sharing of ideas (Barrett and Wilkerson, 2004); however the author has some reservations in this regard.

Finally, in phase three, the student reconsiders their initial reflections. Initial thoughts articulated in phase one are now informed by the multiple views elicited in phase two. The new knowledge or information received in phase two may prompt reconsideration of earlier views, which were relational to the individual only. 
This final reflection stage is an opportunity to articulate personal views which are now informed by multiple views and provides the student with the opportunity to contextualise multiple views, develop new ideas and consider change.

As suggested earlier, such a learning activity, grounded in Prpic's (2005) tri-view or three-stage model for reflexive practice, engages students in processes likely to develop many of the learning outcomes expected in contemporary university settings. Table 1 on the following page identifies abilities which may develop through participation in reflexive practice. The abilities set out in the table are not exhaustive. Levels have not been addressed. The design of the learning activity will determine the degree to which the ability or cognitive function may be developed. 
Table 1: Abilities which may be developed through participation in a tri-view model of reflexive practice

\begin{tabular}{|c|c|c|c|}
\hline & Stage 1 Intra-view & Stage 2 Inter-view & Stage 3 Trans-view \\
\hline $\begin{array}{l}\text { Suggested } \\
\text { Activity }\end{array}$ & $\begin{array}{l}\text { Written, personal reflections } \\
\text { of: } \\
\text { - } \quad \text { provided reading material } \\
\text { - } \quad \text { clinical observation } \\
\text { - } \quad \text { activity or event }\end{array}$ & $\begin{array}{l}\text { Dialogue with peers to elicit } \\
\text { other views and opinions of: } \\
\text { - provided reading material } \\
\text { - clinical observation } \\
\text { - } \quad \text { activity or event }\end{array}$ & $\begin{array}{l}\text { Written, personal reflections } \\
\text { of: } \\
\text { - provided reading material } \\
\text { - clinical observation } \\
\text { - activity or event } \\
\text { informed by multiple } \\
\text { contexts. }\end{array}$ \\
\hline Abilities & $\begin{array}{l}\text { Student may develop an } \\
\text { ability for: } \\
\text { comprehension of } \\
\text { material relevant to } \\
\text { content } \\
\text { demonstration of } \\
\text { comprehension by } \\
\text { articulating (in writing, } \\
\text { orally or some other way) } \\
\text { using appropriate, } \\
\text { technical, discipline- } \\
\text { specific language, in an } \\
\text { organised format } \\
\text { observing the context/s of } \\
\text { the material, observation } \\
\text { or activity } \\
\text { recognising gaps in } \\
\text { personal knowledge or } \\
\text { views and considering } \\
\text { how to fill those gaps } \\
\text { considering why they hold } \\
\text { their current view } \\
\text { evaluation of their view } \\
\text { recognising that personal } \\
\text { experience and } \\
\text { assumptions (and } \\
\text { contexts such as culture, } \\
\text { religion, socio-economic } \\
\text { factors, political leaning, } \\
\text { gender and race) have } \\
\text { shaped personal views } \\
\text { and that other views exist } \\
\text { and may be/are valid } \\
\text { of change and/or } \\
\text { changing personal views } \\
\text { as a result of integrating } \\
\text { external information or } \\
\text { events. }\end{array}$ & 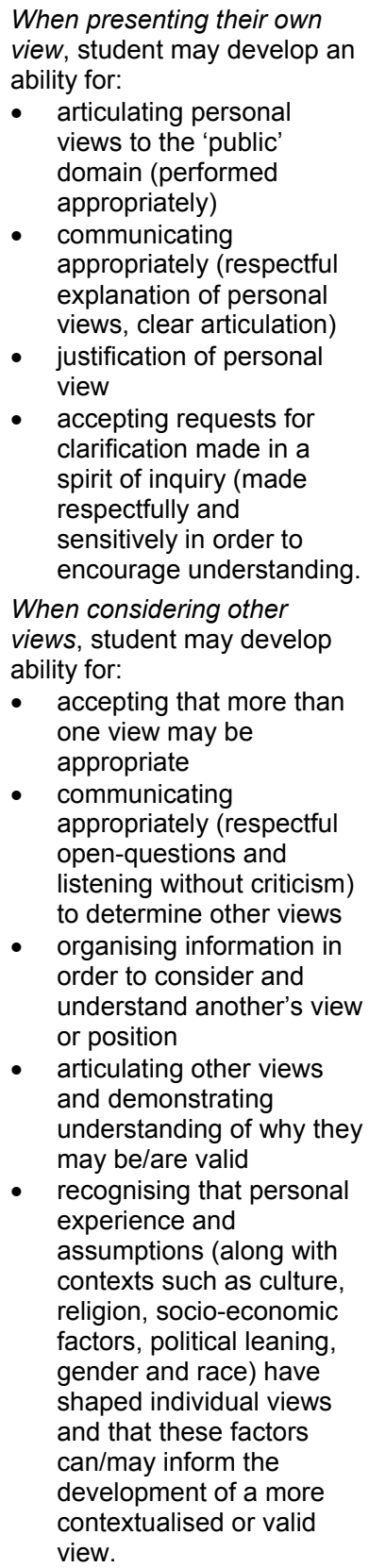 & $\begin{array}{l}\text { Student may develop an } \\
\text { ability for: } \\
\text { - } \quad \text { recognising that new } \\
\text { questions or issues may } \\
\text { arise when other views } \\
\text { are considered } \\
\text { - } \quad \text { organising information in } \\
\text { order to reconsider their } \\
\text { original view or position } \\
\text { - } \quad \text { considering the possibility } \\
\text { of change } \\
\text { changing their view or } \\
\text { position } \\
\text { evaluating multiple views } \\
\text { or contexts } \\
\text { explaining, in a deeper or } \\
\text { more contextualised way, } \\
\text { personal understanding or } \\
\text { position of the content } \\
\text { (event or activity) } \\
\text { - justifying revised personal } \\
\text { view more contextually } \\
\text { recognising learning } \\
\text { - } \text { recognising a } \\
\text { development of idea/s } \\
\text { recognising a deeper } \\
\text { understanding of personal } \\
\text { view } \\
\text { considering and } \\
\text { understanding someone } \\
\text { appreciating or } \\
\text { understanding the } \\
\text { multiple contexts of that } \\
\text { material/observation/ } \\
\text { activity. }\end{array}$ \\
\hline
\end{tabular}

Source: Prpic, J. (2005) Managing academic change through reflexive practice: A quest for new views. Research and Development in Higher Education, 28, 399-406. 


\section{Specific applications of a three stage reflexive practice learning activity}

The paper now turns to a description of two specific learning activities situated in the first year law program at James Cook University. The first, 'reflexive narrative', was trialled in 2005 and evaluated by students and staff. The second, 'book club', is to be trialled in the future with subsequent year level cohorts. Both activities were originally proposed to be situated in the first year subject 'Legal Research Writing and Analysis'. The content in this subject is concerned with sources of law, court hierarchy, the doctrine of precedent, legal reasoning, and statutory interpretation. Like most subjects in the law program, 'Legal Research Writing and Analysis' runs for 13 weeks and each week students are offered a two-hour lecture and a one-hour tutorial.

In addition to the literature on learning referred to earlier, the FYE-Law reform team drew on experiences of teaching first year James Cook University law students and perceived a specific need to improve basic and critical literacy abilities. As a regional university, the James Cook University student profile includes students from low socio-economic families, from rural and remote areas, who are first in their families to attend university and who may not have high levels of prior academic achievement. We sought to facilitate literacy development in a contextualised learning activity within the subject (Ramsden, Beswick, \& Bowden, 1986; Martin \& Ramsden, 1986). Further, engagement was recognised as vital for retention of our students. We recognised that students who engage with peers, university teachers, university processes and the institution are more likely to engage with their learning and complete their study (Krause, Hartley, James, \& McInnis, 2005; Mann, 2001). Accordingly, we sought to personalise the first year experience as much as possible and set out to create an environment which encouraged students to build relationships with peers and teachers (tutors) in educationally purposeful ways (Krause et al., 2005).

\section{Reflective narratives}

The reflective narrative learning activity was designed as a formative assessment activity. At their tutorial each week, students were required to submit a written reflective narrative of around 250 words. Students were encouraged to reflect on their learning processes, knowledge of subject content, or how the law and legal systems affect individuals. Each weekly reflective narrative was read by the student's tutor, who made comments and gave feedback to prompt deeper reflection or consideration of wider views. Feedback given by tutors was deliberately positive, useful and nonjudgmental. This inculcated the value of the learning activity by demonstrating to students that their learning mattered to us and allowed students to feel successful with the activity and their learning. Corrections on grammar and use of legal terminology were also made where necessary and, in addition to handwritten comments, students received a formative, graded, criteriareferenced feedback sheet. The criteria set out on this feedback sheet addressed various learning objectives in the cognitive and affective domains (Bloom et al., 1956; Krathwohl et al., 1964) and described levels of ability for each criterion (see Appendix A).

The weekly writing activity engaged students specifically in phase one, or intra-view reflection (Prpic, 2005). These written reflections were then read by the students' tutor, which involved phase two, or inter-view. This occurred through the ongoing dialogue (reflective narrative pieces were submitted weekly over a period of ten weeks) between the students and their tutor. The tutor would make various written comments which were designed to prompt phase three, or trans-view. This final phase was conducted informally. Students were encouraged to consider their earlier reflections in light of feedback and comments given by the tutor, if they wished to do so. We plan to develop this activity further in the future by requiring students to specifically revisit initial reflections and tutor feedback, in order to reconsider initial views. (Students will collect the feedback on their reflections and, at the end of the course, be required to revisit them and write some final reflections.) It is hoped that this will facilitate more fully the learning benefits of reflexive practice. 
Our evaluations of the reflective narrative activity, as experienced by the 2005 FYE-Law cohort (students and staff) were overwhelmingly positive. A number of students were randomly invited to attend focus group surveys in the final week of the course and staff kept a weekly diary, which contained reflections on the reflective narrative activity. While staff and some students admitted to having initial reservations about the activity as they thought it may be too time consuming, students who participated in the focus groups made many positive comments about it and described the activity as valuable to their learning. Staff involved in the activity were overwhelmed by the level of student participation and were gratified by the improvement in student literacy. A full evaluation of the reflective narrative activity is to be published in an article by Roebuck, Westcott and Thiriet in a 2007 edition of Law Teacher.

\section{Book club}

The book club assessment is to be trialled in 2007 in a final year elective subject (Family Law). The book club activity fully implements Prpic's (2005) three-stage model for reflexive practice, adapted for student learning. This activity requires students to form a book club of around five members with peers from their tutorial group. Each book club will select a piece from a preselected collection of thought provoking readings. Each piece will have broad connection and relevance to the subject content and the role of law in society. After reading the selected piece, each member will write a personal reflection of around 300 words which addresses set questions designed as prompts for reflection. Once all members have completed their initial reflections, each book club will decide whether to meet face-to-face or via a web-discussion board. In this meeting, students will share their views on the reading. The goal for each student should be to come away from this meeting with information which allows them to understand the views of others in the group. Students will be encouraged to ask open questions and it will be emphasised that communication should take place in a spirit of inquiry which is respectful of other views and free of criticism. Students should have sufficient information at the end of the meeting to appreciate and understand the multiple contexts and views of others. After this meeting, students will revisit their initial reflections and answer a second set of questions designed as prompts for contextualising wider views. The final reflection is informed by an appreciation of other perspectives and contexts and it is here that issues previously not thought of may be identified, new ideas may be developed, a deeper learning may take place and consideration of or actual change may occur.

Book club will be implemented as a formative assessment activity. Marks will be allocated for participation in the book club process, that is, for completing the readings, writing reflections and participating in meetings. The substance, content or quality of the reflections will be not graded, however it will be necessary for students to demonstrate that they have attempted an initial and an informed reflection, and that in their final or informed reflection, they have considered other viewpoints (see Appendix B).

\section{Problems and potential of learning activities incorporating reflexive practice}

As a final perspective on reflexive practice to enhance student learning, some potential problems warrant consideration. Firstly, it cannot be assumed that students possess the necessary prerequisite abilities or skills that reflexive practice requires. Participation in reflexive practice requires ability for meaningful engagement in reflection along with interpersonal communication skills which allow for effective and appropriate sharing of views and ideas, and ability for small group or team collaboration. Providing students with clear explanations, demonstrations, examples and instruction will assist in ensuring adequate prerequisite skills. 
The author supports Russell (2005) who notes that a true grasp of the learning activity actualises when the student becomes involved in it. Involvement and participation in the learning activity, which is supported and guided by teachers who provide students with helpful feedback (Biggs, 2003) will allow prerequisite and performance skills or abilities to develop (Russell, 2005).

Secondly, students, particularly first year students, should have a clear model for reflexive practice. Students must be given guidance and feedback to assist with effective engagement in all phases. As reflexive practice may encompass the sharing of personal ideas and views, it is essential that students and staff involved in the learning activity consider two things. Firstly, they should appreciate and value the notion that other views may inform the development of deeper or higher level understandings. Secondly, they should appreciate that communication when articulating and listening to other views, needs to be respectful, non-judgmental and free of criticism (Fernsten \& Fernsten, 2005). If potential problems are appropriately addressed, the benefits of reflexive practice support it as a useful technique to enhance student learning.

The learning activities described above hold much potential for enhancing student learning. Through structured, informal, autonomous, learning activities like book club and reflective narratives, which are based on Prpic's (2005) reflexive practice model, opportunities to synthesise and evaluate new information arise, along with opportunities to consider personal attitudes, beliefs, values and change. Such activities assist with the development of critical literacy and facilitate learning that is highly individual and functional (Biggs, 2003) thus enlivening student learning in all areas of subject content. 


\section{Appendix A}

Reflective narrative learning activity: Example instructions and feedback sheet

Your 250 word reflective narrative may be:

- A reflection on specific skills displayed in the performance of a task.

(For example, writing tasks, group work, task-based learning, study skills)

OR

- $\quad$ A reflection on practical legal knowledge (substantive law and procedure within subject modules).

(For example, a write up of your answer to a tutorial problem)

OR

- A reflection on law in context - how the law and legal systems affect people's lives.

(For example, address an issue that interests you. It may have arisen out of subject content. It could be something like:

Is the adversarial process the best model for adjudication?

Is the per incuriam rule appropriate?)

The following grid is provided to the students in advance. Students submit this grid as a coversheet on their work. Comments are made on the body of their work and appropriate boxes are ticked on this grid as formative feedback. 


\begin{tabular}{|c|c|c|c|c|c|}
\hline Criteria & Standards & & & & \\
\hline & $\begin{array}{l}\text { HD } \\
\text { High } \\
\text { Distinction }\end{array}$ & $\begin{array}{l}\text { D } \\
\text { Distinction }\end{array}$ & C Credit & P Pass & N Fail \\
\hline $\begin{array}{l}\text { Demonstrated } \\
\text { knowledge of topic }\end{array}$ & $\begin{array}{l}\text { Knowledge of } \\
\text { chosen topic is } \\
\text { advanced. } \\
\text { Concepts are } \\
\text { explained and } \\
\text { extended, } \\
\text { questions are } \\
\text { raised and } \\
\text { addressed. }\end{array}$ & $\begin{array}{l}\text { Knowledge of } \\
\text { chosen topic } \\
\text { is advanced. } \\
\text { Concepts are } \\
\text { explained, } \\
\text { questions } \\
\text { raised and } \\
\text { addressed. }\end{array}$ & $\begin{array}{l}\text { Knowledge of } \\
\text { chosen topic } \\
\text { is sound. } \\
\text { Concepts are } \\
\text { explained well. }\end{array}$ & $\begin{array}{l}\text { Knowledge of } \\
\text { chosen topic } \\
\text { is sound. } \\
\text { Concepts } \\
\text { need further } \\
\text { clarification. }\end{array}$ & $\begin{array}{l}\text { A sound } \\
\text { knowledge of } \\
\text { chosen topic } \\
\text { not } \\
\text { demonstrated. }\end{array}$ \\
\hline $\begin{array}{l}\text { Reflection on } \\
\text { chosen topic. } \\
\text { Consider: } \\
\text { identifying issues in } \\
\text { your topic which are } \\
\text { problematic, unfair, } \\
\text { inequitable, } \\
\text { incomplete } \\
\text { evaluating your } \\
\text { topic - is it } \\
\text { good/bad?, } \\
\text { comprehensive? } \\
\text { appropriate? } \\
\text { justifying your } \\
\text { chosen topic and/or } \\
\text { your views } \\
\text { asking is change } \\
\text { appropriate, } \\
\text { required, } \\
\text { unnecessary? } \\
\text { giving imaginative } \\
\text { suggestions for } \\
\text { change/ } \\
\text { improvement }\end{array}$ & $\begin{array}{l}\text { Articulated } \\
\text { clearly. } \\
\text { Contextualised, } \\
\text { (considerations } \\
\text { of other views), } \\
\text { advanced } \\
\text { evaluation of } \\
\text { your view and } \\
\text { concepts along } \\
\text { with justification } \\
\text { and some } \\
\text { consideration } \\
\text { of change. }\end{array}$ & $\begin{array}{l}\text { Articulated } \\
\text { clearly. } \\
\text { Advanced } \\
\text { evaluation of } \\
\text { your view } \\
\text { and concepts } \\
\text { along with } \\
\text { justification } \\
\text { and some } \\
\text { consideration } \\
\text { of change. }\end{array}$ & $\begin{array}{l}\text { Articulated } \\
\text { clearly. Some } \\
\text { evaluation of } \\
\text { your view and } \\
\text { concepts with } \\
\text { justification } \\
\text { and some } \\
\text { consideration } \\
\text { of change. }\end{array}$ & $\begin{array}{l}\text { Articulated } \\
\text { clearly. Some } \\
\text { evaluation of } \\
\text { your view and } \\
\text { concepts. }\end{array}$ & $\begin{array}{l}\text { Articulation } \\
\text { unclear and } \\
\text { maybe not } \\
\text { appropriate or } \\
\text { substantiated. }\end{array}$ \\
\hline $\begin{array}{l}\text { Clarity of expression } \\
\text { (including spelling, } \\
\text { grammar, } \\
\text { punctuation) and } \\
\text { overall structure }\end{array}$ & $\begin{array}{l}\text { Fluent writing } \\
\text { style } \\
\text { appropriate to } \\
\text { document. } \\
\text { Grammar and } \\
\text { spelling } \\
\text { accurate. } \\
\text { Appropriate } \\
\text { and clear } \\
\text { structure }\end{array}$ & $\begin{array}{l}\text { Language } \\
\text { fluent. } \\
\text { Grammar } \\
\text { and spelling } \\
\text { accurate. } \\
\text { Appropriate } \\
\text { and clear } \\
\text { structure. }\end{array}$ & $\begin{array}{l}\text { Language } \\
\text { mainly fluent. } \\
\text { Grammar and } \\
\text { spelling mainly } \\
\text { accurate. } \\
\text { Structure } \\
\text { apparent. }\end{array}$ & $\begin{array}{l}\text { Meaning } \\
\text { apparent but } \\
\text { language not } \\
\text { always fluent. } \\
\text { Grammar } \\
\text { and/or spelling } \\
\text { contain errors. } \\
\text { Some } \\
\text { structure. }\end{array}$ & $\begin{array}{l}\text { Meaning } \\
\text { unclear and/or } \\
\text { grammar } \\
\text { and/or spelling } \\
\text { contain } \\
\text { frequent } \\
\text { errors. Lack of } \\
\text { structure. }\end{array}$ \\
\hline $\begin{array}{l}\text { Conformity with } \\
\text { instructions }\end{array}$ & & \multicolumn{3}{|l|}{$\begin{array}{l}\text { Work has } \\
\text { been } \\
\text { submitted on } \\
\text { time and } \\
\text { narrative } \\
\text { complies with } \\
\text { word limit. }\end{array}$} & $\begin{array}{l}\text { Work has } \\
\text { been } \\
\text { submitted late } \\
\text { with no reason } \\
\& / \text { or deviates } \\
\text { significantly } \\
\text { from word limit } \\
\text { requirement. }\end{array}$ \\
\hline
\end{tabular}

Source: Guidance was taken from Webb, J., \& Maughan, C. (Eds). (1996). Teaching lawyer's skills. London: Butterworths. Also Hinett, K. (2002). Developing reflective practice in legal education (p. 40). London: UK Centre for Legal Education. (This grid is also published in an article by Roebuck, Westcott and Thiriet in a 2007 edition of Law teacher.) 


\section{Appendix B}

Book club learning activity: Example criteria and standards sheet

\begin{tabular}{|c|c|c|}
\hline Criteria & Standards & \\
\hline Book club reading & $\begin{array}{l}\text { Readings were completed on } \\
\text { time. }\end{array}$ & Readings were not completed. \\
\hline $\begin{array}{l}\text { First reflection } \\
\text { (after reading completed - } \\
\text { before meeting) } \\
\text { Student has addressed set } \\
\text { questions and engaged in } \\
\text { reflection. }\end{array}$ & $\begin{array}{l}\text { Student has handed in written } \\
\text { responses to set questions } \\
\text { which articulate what they think. } \\
\text { For example, by using 'l” } \\
\text { statements like: } \\
\text { I thought the author ... } \\
\text { I agree/disagree ... } \\
\text { I have experienced a similar ... } \\
\text { I didn't relate to ... because ... } \\
\text { OR } \\
\text { Student has handed in written } \\
\text { responses to the reading which } \\
\text { address identified issues, } \\
\text { relevant to them. }\end{array}$ & $\begin{array}{l}\text { Student has not handed in } \\
\text { written responses to set } \\
\text { questions. } \\
\text { OR } \\
\text { Student has handed in a } \\
\text { response which does not } \\
\text { address the set questions and } \\
\text { does not identify any other } \\
\text { issues in the reading. }\end{array}$ \\
\hline $\begin{array}{l}\text { Attended and participated in } \\
\text { meeting }\end{array}$ & $\begin{array}{l}\text { Student has: } \\
\text { - attended and participated in } \\
\text { book club meetings } \\
\text { - } \quad \text { tried to understand other views } \\
\text { by use of open questions and } \\
\text { "Why ..." questions to seek } \\
\text { clarity } \\
\text { - } \quad \text { tried to communicate their } \\
\text { view/s } \\
\text { - encouraged others to articulate } \\
\text { their view/s and shown respect } \\
\text { by listening and seeking to } \\
\text { understand. } \\
\end{array}$ & $\begin{array}{l}\text { Student has attended and } \\
\text { participated in book club } \\
\text { meetings. } \\
\text { OR } \\
\text { Student has attended but has } \\
\text { been either discouraging of } \\
\text { others, critical and disrespectful } \\
\text { of other views and/or has failed } \\
\text { to listen. }\end{array}$ \\
\hline $\begin{array}{l}\text { Second reflection } \\
\text { (after meeting) } \\
\text { Student has addressed set } \\
\text { questions and engaged in } \\
\text { reflection which considers other } \\
\text { views. }\end{array}$ & $\begin{array}{l}\text { Student has handed in written } \\
\text { response to set questions which } \\
\text { demonstrates that they have } \\
\text { considered in some way other } \\
\text { views/opinions/etc. and have } \\
\text { maybe identified new issues } \\
\text { and ideas. } \\
\text { OR } \\
\text { Student has handed in written } \\
\text { response to the reading which } \\
\text { demonstrates they have in } \\
\text { some way considered other } \\
\text { views/opinions/etc. and have } \\
\text { maybe identified new issues } \\
\text { and ideas. }\end{array}$ & $\begin{array}{l}\text { Student has not handed in } \\
\text { written responses to set } \\
\text { questions. } \\
\text { OR } \\
\text { Student has handed in a } \\
\text { response which does not } \\
\text { address the set questions and } \\
\text { does not identify any other } \\
\text { issues in the reading. }\end{array}$ \\
\hline
\end{tabular}




\section{References}

Argyris, C., \& Schon, D. (1974). Theory in practice: Increasing professional effectiveness. San Francisco: Jossey-Bass.

Barrett, H. C. (2001). Electronic portfolios - A chapter in educational technology. Retrieved October 6, 2005, from http://electronicportfolios.org/portfolios/encyclopediaentry.htm

Barrett, H., \& Wilkerson, J. (2004). Conflicting paradigms in electronic portfolio approaches. Retrieved 6 October, 2005, from http://helenbarrett.com/systems/paradigms.html\#motivation.

Biggs, J. B. (2003). Teaching for quality learning at university: What the student does (2nd. ed.). Buckingham, UK: Society for Research into Higher Education and Open University Press.

Biggs, J. B., \& Collis, K. F. (1982). Evaluating the quality of learning: The SOLO taxonomy (Structure of the observed learning outcome). New York: Academic Press.

Biggs, J. B., \& Moore, P. J. (1992). The process of learning (3rd. ed.). Sydney: Prentice Hall.

Bloom, B.S. (Ed.). Engelhart, M. D., Furst, E. J., Hill, W. H. \& Krathwohl, D. R. (1956). Taxonomy of educational objectives: The classification of educational goals: Handbook I: The cognitive domain. New York: Longman.

Boud, D. (1999). Avoiding the traps: Seeking good practice in the use of self assessment and reflection in professional courses. Social Work Education, 18(2), 121-132.

Brockbank, A., \& McGill, I. (1998). Facilitating reflective learning in higher education. Buckingham, UK: Society for Research into Higher Education and Open University Press.

Brookfield, S. D. (1995). Becoming a critically reflective teacher. San Francisco: Jossey-Bass).

Fernsten, L., \& Fernsten, J. (2005). Portfolio assessment and reflection: Enhancing learning through effective practice. Reflective Practice, 6(2), 303-309.

Gibbs, G. (1993). The nature of quality in learning in improvement of student learning. Bristol: Technical and Education Services.

Giddens, A. (1990). The consequences of modernity. Stanford, CA: Stanford University Press.

Giddens, A. (1991). Modernity and self-identity: Self and society in the late modern age. Cambridge: Polity Press.

Giddens, A. (2001). Sociology (4th. ed.). Cambridge: Polity Press in Association with Blackwell Publishers Ltd.

Havemann, P. (1995). Law in context - Taking context seriously. Waikato Law Review, 3, 137.

Havemann, P. (1997). Modernity, commodification and social citizenship. Yearbook of New Zealand Jurisprudence, 1, 17-57.

Havemann, P., \& Mackinnon, J. (2002) Synergistic literacies: Fostering critical and technological literacies in teaching a legal research methods course. Legal Education Review, 13(1), 65-92.

Henriss-Anderssen, D. (2002). Teaching legal ethics to first year law students. Legal Education Review, 13(1), 45.

Hinett, K. (2002). Developing reflective practice in legal education. Available from UK Centre for Legal Education website: http://www.ukcle.as.uk/resources/reflection/index.html

Keyes, M., \& Orr, G. (1996). Giving theory 'a life': First year student conceptions of legal theory. Legal Education Review, 7(1), 31.

Kift, S. (2005). First year renewal to engage learners in law. Retrieved July 2, 2005, from http://www.fyhe.qut.edu.au/FYHE_Previous/papers03/Refereed\%20Papers/Full\%20papers/ Kift_paper.doc . 
Krathwohl, D., Bloom, B., \& Masia, B. (1964). Taxonomy of education objectives: The classification of education goals: Handbook II: The affective domain. New York: Longman.

Kratzing. (1990). Metalearning and the facilitation of learning. Lecture presented at the Eighth Australasian Learning and Language Conference, Queensland University of Technology Counselling Services, Brisbane, Australia.

Krause, K. (2005, 21 September) Engaged, inert or otherwise occupied? Deconstructing the 21st century undergraduate student. Lecture presented at the James Cook University, Sharing Scholarship in Learning and Teaching Symposium, Townsville and Cairns, Australia.

Krause, K., Hartley, R., James, R., \& McInnis, C. (2005). The first year experience in Australian universities: Findings from a decade of national studies. Department of Education, Science and Training, Australian Government. Retrieved (n.d.) from http://www.dest.gov.au/sectors/higher_education/publications_resources/profiles/ first_year_experience.htm

Le Brun, M., \& Johnstone, R. (1994). The quiet revolution: Improving student learning in law. Sydney: The Law Book Company Limited.

Le Brun, M., \& Macduff, A. (2005). Developing the reflective practitioner online (in law). The Law Teacher, 39(1), 16-28.

Mann, S. (2001). Alternative perspectives on the student experience: Alienation and engagement, Studies in Higher Education, 26(1), 4-19.

Martin, E. \& Ramsden, P. (1986). Learning skills or skill in learning? In J. A. Bowden (Ed.), Student Learning: Research into practice. University of Melbourne: Centre for the Study of Higher Education.

Mezirow, J. (1981). A critical theory of adult learning and education. Adult Education, 32(1), $3-24$.

Moon, B. (1994). Rethinking resistance: English and critical consciousness. Interpretations, 27(3), 48-69.

Prpic, J. (2005). Managing academic change through reflexive practice: A quest for new views. Research and Development in Higher Education, 28, 399-406.

Ramsden, P., Beswick, D., \& Bowden J. (1986). Effects of learning skills interventions on first year university students' learning. Human Learning, 5, 151-164.

Rees, C., Shepherd, M., \& Chamberlain, S. (2005). The utility of reflective portfolios as a method of assessing first year medical students' personal and professional development. Reflective Practice, 6(1), 3.

Russell, T. (2005). Can reflective practice be taught? Reflective Practice, 6(2), 199-204.

\section{Acknowledgements}

I would like to thank Dr Kay Martinez from the Teaching and Learning Development Unit at James Cook University for her time and assistance in developing this paper and Lisa Westcott from the Law School at James Cook University for her comments and intra-view discussion. Thanks to all of the staff at James Cook University Law School who were involved in the FYELaw redesign project and thanks to thank Professor Paul Havemann (Head of School, JCU Law School) who sparked my interest in reflexive practice. Finally, thanks to Dr J Kaya Prpic for her tri-view model for reflexive practice which was the inspiration for this paper and the learning activities described.

Copyright (c) 2007 Roebuck. 